\title{
The influence of professional training disciplines on the physical fitness level of the folk dance department students
}

\author{
Olga V. Limanskaya ${ }^{1 \mathrm{ABD}}$, Irina V. Kriventsova ${ }^{1 \mathrm{ABCDE}}$, Leonid V. Podrigalo ${ }^{2 \mathrm{BCD}}$,Olena V. Yefimova ${ }^{1 \mathrm{BE}}$, \\ Marina Jagiello ${ }^{3 \mathrm{BCD}}$ \\ ${ }^{1}$ H.S. Skovoroda Kharkiv National Pedagogical University, Ukraine \\ ${ }^{2}$ Kharkiv State Academy of Physical Culture, Kharkov, Ukraine \\ ${ }^{3}$ Gdansk University of Physical Education and Sport, Poland.
}

Authors' Contribution: A - Study design; B - Data collection; C - Statistical analysis; D - Manuscript Preparation; E - Funds Collection.

\begin{abstract}
Purpose:

To determine the influence of professional training disciplines on the physical fitness level of the folk dance department students.

Material: $\quad$ The study involved students majoring in "Choreography" (males $-n=5$; females $-n=10$ ). Tests were used to determine the level of general and special physical qualities development. It was also determined the level of physical fitness at the beginning of training and after two years of training.

Results: $\quad$ At the beginning of the study, students had average and low rates of speed and strength qualities development and low indicators of dorsal spine mobility. There were significant changes in increasing the level of coordination and dorsal spine mobility $(p<0.01)$. The increase in average statistical indicators of strength endurance is in males $(p<0.05)$ and females $(p<0.01)$. It was revealed the decrease in the level of certain indicators of general physical fitness in females during the first two years of study.

Conclusions: It is recommended to constantly monitor the physical fitness of future choreographers. The exclusion of the discipline "Physical Education" from the training programs for choreography teachers requires appropriate compensation for specific physical activity. These can be students' independent physical training. It also requires the correction of special training programs that include physical activity.

Keywords: physical fitness, choreography, professional training, professional disciplines, teacher.
\end{abstract}

\begin{abstract}
Glossary:
Aplomb - Ability to keep all parts of the body in balance. Confidence and freedom of dance performance.

Exercice - The first part of a classical dance lesson. Movements near barre and in the middle of the hall in the appropriate sequence. They form and improve professional qualities for performing dance technique: turnout ability, leg muscle strength, body posture, head, hands, coordination, aplomb.
\end{abstract}

Allegro - Part of a classical dance lesson, which consists of jumps (low, average, high).

Allonge - Position in classical dance. It is based on the principle of straightening the rounded positions of the hands (arrondi).

Plie - Bent, bending. A bending of the knee or knees. This is an exercise to render the joints and muscles soft and pliable and the tendons flexible and elastic, and to develop a sense of balance.

Arabesque - One of the basic poses in ballet. In ballet it is a position of the body, in profile, supported on one leg. Sissonne Fermée - Closed sissonne. A step of low elevation performed to a quick tempo.

Port De Bras - Carriage of the arms. The term port de bras has two meanings: (1) A movement or series of movements made by passing the arm or arms through various positions. The passage of the arms from one

\footnotetext{
c) Olga V. Limanskaya, Irina V. Kriventsova, Leonid V. Podrigalo,

Olena V. Yefimova, Marina Jagiello, 2020

doi:10.15561/26649837.2020.0505
}

position to another constitutes a port de bras. (2) A term for a group of exercises designed to make the arms move gracefully and harmoniously.

\section{Introduction}

The deterioration of students' health is due to the socio-economic environment, reduced physical activity, insufficient motivation for a healthy lifestyle, lack of a culture of self-development of individual physical qualities. In this context, the problem of the physical fitness of students in higher education institutions becomes especially important.

The majority of young people have a low level of physical fitness; no need for physical exercise and mastering the values of physical culture $[1,2,3]$. The physical fitness of the folk dance department students is an indicator of readiness for physical activity, provided by the educational program in the major "Choreography". The level of physical fitness creates a basis for further development of technical and stage qualities of future professionals.

Kuznetsova et al. [4] determined the level of physical fitness of 1st-year students of the university: $37 \%$ - had lower than average; $21 \%$ - average; $28 \%$ - low. The comparative analysis of students from different higher education institutions did not reveal a high level of physical fitness [5]. The author found out that the lowest level of indicators is observed in aerobic endurance. Shchur [6] determined the level of physical condition 
in art specialties students. The author proves that it corresponds to the average level. Marinchuk [7] revealed the features of physical fitness in creative specialties students. The author found out the decrease in indicators during training. The need for strength endurance and dorsal spine mobility development is also substantiated.

The improving choreographic skills lead to the search for adequate approaches to the professional and practical training of future teachers of choreographic disciplines. The choreographic activity combines a high level of performance and high artistic and emotional culture. The requirements for the overall quality of choreographers' training are becoming higher [8]. Choreographic training includes a set of disciplines that form a range of professional competencies.

The main criteria of professional selection of choreographers for training in educational institutions are the following: health, turned foot, dorsal spine mobility, plié, maximum leg height, the ability to jump high, coordination [9]. Most authors prefer dorsal spine mobility. It is a necessary condition for the graceful performance of dance movements. Petrovich et al. [10] determined that after 13-14 years it is necessary to perform stretching exercises. Under other conditions, dorsal spine mobility can decrease significantly in 16-17 years. Namely, this age category of students is the largest in the 1st year of study.

The asthenic type of the dancer's body is preferred in the choreography art: graceful lines, long legs, narrow shoulders, short torso, feet turned outwards. These requirements are caused not only by the aesthetic principles of the art of dance. The dancer's body balance makes it easier to overcome the load and overload of professional activity. Also, the choreographer needs muscle strength $[6,11]$. It allows performing the complex of physical exercises with external resistance or response. Blagova [12] emphasized that the professional competencies of a choreographer are an organic combination of essential professional characteristics, personal significant qualities, and abilities.

The following competencies of the future teacher of choreography are the same important: physical endurance; motor activity; agility; ability to distribute different types of physical activity; perform relax exercises; to use in practice the knowledge of physical culture, anatomy, physiology, hygiene, medicine [13-15]. The professional activity of a choreographer is associated with high motor activity and excessive physical activity $[16,17]$. Strength endurance is an important guarantee of a dancer's health and creative longevity.

The ability of aplomb in choreography is an important component of professional growth. This is performed in the ability to fix a given position in space [17]. The sense of balance is important for performing many movements and poses of different types of dance.

It is recommended to include in choreographic training exercises of general and special physical training [17, 18]. This expands the ability to adapt to unexpected changes in professional activities. It also promotes body recovery and increases readiness for modern living requirements.

The study of the plyometric training impact on improving the physical fitness of choreographed students showed the following: increasing the explosive strength of the legs (37\%); vertical jump height (8.3\%); abdominal strength $(22 \%)$ [18]. The work of all muscles and joints is subordinated to the basic movements of modern ballroom dance. They include the "complex of special exercises" for the whole body: coordination movements complex in European dance program ("slow waltz", "tango", "slow foxtrot", "quick step", "Viennese Waltz") and Latin American dance program ("samba", «Rumba», «chacha-cha», "pasodoble», «jive») [17].

Modern dance is an effective means of physical training. It is a synthesis of physical culture and art $[19,20]$. The study of different styles of modern dance (contemporary, modern dance, jazz dance, hip-hop, jazz fank) involves mastering the various techniques of working with the body, breathing, consciousness.

The professional training of future choreography teacher is comprehensive $[21,22]$. It includes the special disciplines' mastering by students. These disciplines are aimed at forming the basic qualities of a teacher, dancer, choreographer-director. The majority of educational institutions independently develop a training program for dance specialists. There is a need to implement an effective educational program that can ensure sufficient physical development of students. This approach makes it possible to improve the professional ability to perform professional functions.

The cycle of professional training of choreographers is aimed at the formation of the following competencies: improving the practical skills of choreographic performance, dance improvisation, work with movement and its various forms; ability to reproduce dance movements and compositions in an ensemble. Considerable attention in professional disciplines should be paid to the development of physical qualities of students (special coordination of movements, dorsal spine mobility, muscle strength, agility, and endurance). The student's physical fitness is one of the criteria of health and an important factor in his professional training effectiveness. Consequently, the method of organizing and conducting practical professional training requires improvement. It is also necessary to search for the new forms and methods of conducting training and organizing the educational process.

The purpose of the study is to determine the influence of professional training disciplines on the physical fitness level in folk dance department students.

\section{Material and Methods}

Participants. The study involved students (males $-\mathrm{n}=$ 5; females $-\mathrm{n}=10$ ) majoring in "Choreography" (Faculty of Arts, Folk Dance Subdivision, H.S. Skovoroda Kharkiv National Pedagogical University, Ukraine). At the beginning of the study, the average age of participants was $17.2 \pm 1.8$ years.

Research Design. The study was conducted for two 
years at the Choreography Department (H.S. Skovoroda Kharkiv National Pedagogical University, Ukraine). The students have 16 hours per week of professional disciplines. In September 2017 and in September 2019, the same students took the tests. Educational program for student's training exclude the discipline "Physical Education". The development of physical qualities is the task of special disciplines in the course of professional training. The distribution of general and special physical activities of the training class in percentage is the following:

1) General warm-up - $10 \%$;

2) Bar-work exercice - $20 \%$;

3) Exercices in the middle of the hall, with allegro $20 \%$;

4) trick elements and spins - 20\%;

5) Study and improvement of dance exercises - 15\%;

6) Stretching exercises and floor barre - $15 \%$.

The general physical fitness (GPF) of students was determined using the following exercises:

Test 1. 4x9 m Shuttle test, sec. [23, 24].

Test 2. Standing Long Jump Test (Broad Jump), cm $[23,24]$.

Test 3. Vertical Jump Test (Sargent Jump), cm. [25, 26].

Test 4. President's Challenge Curl-Up Test (for 60 sec.), quantity of times [27].

Test 5. Seated Forward Bend, cm [28].

Test exercises to identify special physical fitness (SPF) are the following:

Test 6. Gymnast bridge (modified). Equipment: gymnastic mat. Description: The student performs the Gymnast bridge, then shortens the distance between the heels and fingertips.

This position is held for 2 sec. The test is repeated twice. The test result is the distance between the heels and the fingertips. The best of the two attempts is counted. Note: watch the wrists and the body balance. If the participant does not fully straighten the elbows, the exercise is a failure.

Test 7. Right split. Equipment: gymnastic bar $(20 \mathrm{~cm}$ height). Description: starting position it the third position [29]; the right foot bears by the heel on the Gymnastic bar; the toe is pointed. The exercise Right split is performed at the command "Go". The student bears by his palms on the floor, the body leans forward.

The lower position is fixed for $2 \mathrm{sec}$. The test is repeated twice.

The test result is the best distance between the floor and the lower point of the pelvis (coccyx).

Note: the exercise should be performed smoothly; both legs should form one line. If the participant bends his legs at the knees, the attempt is a failure.

Test 8. Side split. Equipment: gymnastic bar $(20 \mathrm{~cm}$ height). Description: starting position is the first position [29], the right foot bears by the heel on the Gymnastic bar; the toe is pointed. The exercise Side split is performed at the command "Go". The student bears by his palms on the floor, the body leans forward.
The lower position is fixed for 2 sec. The test is repeated twice.

The test result is the best distance between the floor and the lower point of the pelvis (coccyx).

Note: the exercise should be performed smoothly; both legs should form one line. If the participant bends his legs at the knees, the attempt is a failure.

Test 9. Sissonne fermée. Equipment: non-skid surface with a line and marking in centimeters. Description: the participant stand at the line in the fifth position [29]; right foot in front.

At the command "Go" student:

- opens his arms in the allongé (back straight);

- squats;

- jumps forward (perform a swing with the right foot forward).

After the jump, the student returns to the fifth position [29]; in plié on both feet. The test result is a jump distance in centimeters, the best of the two attempts. Note: if during the jump the participant bends his knees, does not point the toe, the attempt is a failure.

Test 10. Jumps on the spot with bent legs. Equipment: non-skid surface with a mark, stopwatch. Description: The participant stands at the mark in the sixth position [29], hands on the waist. The student jumps up at the command "Go" (both legs are bent, his back is kept straight).

The test result is the number of jumps per minute. Note: In jumping, the heels should touch the buttocks and the toes should be pointed. If the participant leaves the mark, the attempt is a failure.

Test 11. Balance maintaining in the "arabesque".

Equipment: non-skid surface with the line, stopwatch. Description:

- the participant stands at the line,

- right leg in the turnout position,

- flat left foot leads back to the toe,

- The arms open into the first position "arabesque" (right foot forward and left foot sideways in the allongé).

The student raises the left leg in the turnout position on 90 degrees at the command "Go". The position "arabesque" is kept as long as possible. The test result is the number of sec of keeping the position without body vibrations. Note: both legs should be pointed at the knees, the toes pointed as much as possible, back is straight. The attempt is a failure if the participant puts down his left leg earlier than in $10 \mathrm{sec}$.

Statistical analysis. We used the statistical analysis program SPSS 20. For each variable was calculated: $\mathrm{X}$ - arithmetic mean; $\mathrm{s}-$ the standard deviation; $\Delta \mathrm{x}-$ the marginal sampling error for the mean; $t$ - Student's criterion; $\mathrm{p}$ - the significance level. The significance of differences in groups was estimated using parametric indicators (Student's criterion) and non-parametric indicators (Wilkinson-Mann-Whitney criterion, Rosenbaum criterion).

\section{Results}

It was determined low indicators in the Seated Forward Bend test (Test 5) in students at the beginning of 1 year 
of study. It was determined the average level of indicators of special dorsal spine mobility. The highest indicator in females was in test $7(9.4 \mathrm{~cm} \pm 2.16)$. At the beginning of the study, no students with a high level of general and special physical fitness were identified. The lowest results are observed in the indicators of strength training, dorsal spine mobility, and agility. Significantly better indicators were found in explosive strength in males and females (Test 2); strength endurance in males (Test 9). The results of the general physical fitness of students in 1 and 3 years of study under the influence of professional training disciplines are presented in Table 1.

Significant changes in the dynamics of females' indicators took place in the following tests: females test $4(\mathrm{t}=5.84, \mathrm{z}=0)$, test $3(\mathrm{z}=3)$ and test $5(\mathrm{z}=1)$. The results in tests $1,2,3$ (Table 1 , females) were on downtrend.

The results of males' testing indicate significant changes in test $4(\mathrm{t}=-2.62, \mathrm{z}=0)$ and test $3(\mathrm{t}=-4.82, \mathrm{z}$ $=0)$. The results of test 5 also have positive changes. The results of tests 1,2 are on uptrend insignificantly (Table 1).

The special physical fitness of students was determined by testing special exercises. The dynamics of changes in indicators in special tests for 1 and 3 courses are presented in Table 2.

The females had a significant change in all indicators of selected tests of special physical training (Table 2), as follows: in test $6(\mathrm{t}=4.26, \mathrm{z}=0)$, in test $7(\mathrm{t}=2.57, \mathrm{z}=0)$, in test $8(\mathrm{t}=2.03, \mathrm{z}=0)$, in test $9(\mathrm{t}=-4.57, \mathrm{z}=0)$, in test $10(\mathrm{t}=-2.72, \mathrm{z}=1)$, in test $11(\mathrm{t}=-2.05, \mathrm{z}=0)$.

In males the probable changes in results of special physical exercises testing are observed as follows: test 7 $(\mathrm{t}=2.03, \mathrm{z}=0)$, test $8(\mathrm{z}=0)$, test $11($ tab. 2$)$. Test $9(\mathrm{z}=$ 0 ) males perform at the average level (Table 2 ).

There was an increase in the average values of explosive strength and strength endurance: males - test $3(\mathrm{z}=0)$ and test 10 ; females - test 10. Both males and females have increased coordination level (test 11). The positive dynamics of the Seated Forward Bend test (females, males) indicates the effectiveness of the special dorsal spine mobility program.

The results of the study showed significant changes in the indicators of students' special physical fitness. The level of certain indicators of general physical fitness in females is on a downtrend (test 1,2,3).

\section{Discussion}

Our study was aimed at determining the level of physical qualities of students under the influence of

Table 1. The dynamics in indicators of students' general physical fitness

\begin{tabular}{|c|c|c|c|c|c|c|}
\hline \multirow[b]{2}{*}{ Tests } & \multicolumn{3}{|c|}{ Females $(n=10)$} & \multicolumn{3}{|l|}{ Males ( $n=5)$} \\
\hline & $\begin{array}{l}\text { Beginning of } \\
\text { the study }\end{array}$ & $\begin{array}{l}\text { End of the } \\
\text { study }\end{array}$ & $\mathbf{p}$ & $\begin{array}{l}\text { Beginning of } \\
\text { the study }\end{array}$ & $\begin{array}{l}\text { End of the } \\
\text { study }\end{array}$ & $\mathbf{p}$ \\
\hline 1. 4x9 m Shuttle test, sec. & $10.87 \pm 0.17$ & $10.88 \pm 0.25$ & 0.929 & $9.53 \pm 0.20$ & $9.45 \pm 0.26$ & 0,59 \\
\hline $\begin{array}{l}\text { 2. Standing Long Jump Test } \\
\text { (Broad Jump), cm }\end{array}$ & $180.40 \pm 2.30$ & $179.90 \pm 2.66$ & 0.495 & $216.75 \pm 4.89$ & $222.00 \pm 1.78$ & 0,23 \\
\hline $\begin{array}{l}\text { 3. Vertical Jump Test (Sargent } \\
\text { Jump), cm. }\end{array}$ & $39.20 \pm 1.28$ & $38.00 \pm 1.58$ & 0.585 & $50.25 \pm 0.63$ & $55.00 \pm 0.91 *$ & 0,04 \\
\hline $\begin{array}{l}\text { 4. President's Challenge Curl- } \\
\text { Up Test (for } 60 \mathrm{sec} \text { ), quantity } \\
\text { of times }\end{array}$ & $37.20 \pm 1.28$ & $46.80 \pm 1.03 *$ & 0.000 & $53.25 \pm 1.38$ & $60.50 \pm 2.40 *$ & 0,01 \\
\hline 5. Seated Forward Bend, cm & $9.50 \pm 1.27$ & $11.20 \pm 1.24$ & 0.001 & $6.00 \pm 2.31$ & $9.75 \pm 2.17$ & 0,00 \\
\hline
\end{tabular}

* - differences are significant according to Student's criterion.

Table 2. The dynamics in indicators of students' special physical fitness

\begin{tabular}{|c|c|c|c|c|c|c|}
\hline \multirow[b]{2}{*}{ Tests } & \multicolumn{3}{|c|}{ Females $(n=10)$} & \multicolumn{3}{|l|}{ Males $(n=5)$} \\
\hline & $\begin{array}{l}\text { Beginning of } \\
\text { the study }\end{array}$ & $\begin{array}{l}\text { End of the } \\
\text { study }\end{array}$ & $\mathbf{p}$ & $\begin{array}{l}\text { Beginning of } \\
\text { the study }\end{array}$ & $\begin{array}{l}\text { End of the } \\
\text { study }\end{array}$ & $\mathbf{p}$ \\
\hline 6. Gymnast bridge, $\mathrm{cm}$ & $56.10 \pm 0.77$ & $51.10 \pm 0.89 *$ & 0.000 & $57.00 \pm 3.49$ & $53.75 \pm 3.57$ & 0.01 \\
\hline 7. Right split, cm & $9.40 \pm 1.15$ & $5.20 \pm 1.16^{*}$ & 0.000 & $14.25 \pm 1.44$ & $10.75 \pm 0.95 *$ & 0.01 \\
\hline 8. Side split, cm & $14.00 \pm 1.70$ & $9.30 \pm 1.56 *$ & 0.000 & $16.00 \pm 3.34$ & $12.50 \pm 2.84$ & 0.01 \\
\hline 9. Sissonne fermée, cm & $54.60 \pm 0.99$ & $60.60 \pm 0.86^{*}$ & 0.000 & $53.75 \pm 1.49$ & $56.75 \pm 0.85$ & 0.13 \\
\hline $\begin{array}{l}\text { 10. Jumps on the spot with } \\
\text { bent legs, quantity of times } \\
\text { for } 60 \mathrm{sec}\end{array}$ & $79.60 \pm 1.54$ & $60.60 \pm 1.87^{*}$ & 0.000 & $92.75 \pm 2.14$ & $97.25 \pm 3.64$ & 0.08 \\
\hline $\begin{array}{l}\text { 11. Balance maintaining in } \\
\text { «arabesque», sec }\end{array}$ & $38.60 \pm 1.79$ & $44.00 \pm 1.93^{*}$ & 0.000 & $41.50 \pm 2.53$ & $45.75 \pm 3.25$ & 0.02 \\
\hline
\end{tabular}

* - differences are significant according to Student's criterion 
professional training disciplines. The obtained results confirm the conclusions of Shchur [5] about the physical condition level of the art specialties students. The results correspond to the average level.

During the two years of study, females showed a downtrend of the results in tests $1,2,3$. The attention should be paid to the development of speed and strength for the harmonious physical condition of females. We could partially agree with the research of Marinchuk [7] on the peculiarities of physical fitness of the art specialties students. The author emphasizes the decrease of these indicators during training. He has also justified the need to develop strength endurance and dorsal spine mobility.

We agree with the results of Chuba [14] and Wang Yang et al. [30] studies. We emphasized that the professional training of future choreography teachers for various types of work (organizational and creative, performance, choreography, teaching) creates opportunities for students to master important professional competencies.

The significant place in the professional training of future choreography teachers is given to technical training. The technical training level directly depends on the level of physical fitness. Mastering the technique of complex movements (medium and large jumps, pirouettes, trick elements of dance) is impossible without the physical ability to perform them.

High and difficult jumps (sissonne fermée in I, II, III arabesque, pas ballone, pas de chat, grand pas assemble en tournant) require: vigorous grips of the hands and lower part of the working leg; swinging movements of the torso, hands, working leg; clarity of head turns in the corresponding positions. Such jumps should be coordinated according to the tempo and rhythm of the musical accompaniment.

Dexterity and coordination of movements are extremely important for folk dance. The majority of practicing trainers consider the development of dexterity and coordination in the complex $[17,31,32]$. We agree with the opinion of experts that the dexterity development is achieved by: the use of complex coordination exercises and exercises with elements of suddenness; performing exercises based on sound or visual signals that correspond to a change in the direction of movement or a change in the movement itself. To be agile and coordinated in choreography is to meet the following requirements: to quickly master new movements of different types of dance and improve them; change movements quickly enough in accordance with the proposed circumstances; master complex coordination exercises in different types and styles of dance; perform movements accurately and correctly.

The program for the students' special physical fitness development in the methodology of teaching choreographic disciplines provides the abovementioned components. The exercise near the bar of classical and folk-stage dance is composed in such a way that the muscles are gradually included in the work: from the ankle (demi and grand plié, batement tendu, batement tendu jeté) to the hip joints (rond de jamb par terre, batement foundu, batement frappé, adajio, grand batement jeté). This is a well-known principle in learning - from simple to complex.

Our study confirms the effectiveness of the special dorsal spine mobility development. Insufficient flexibility in the hip joint leads to a decrease in turnout in the knee joint and the ankle. This leads to complications in performing jumps and squats. Limited dorsal spine mobility does not allow you to perform movements properly with maximum amplitude: different types of port de bras, arabesque. The active dorsal spine mobility becomes especially important in the process of choreography training. The active dorsal spine mobility is realized in performing specific dance movements and exercises with high amplitude. Passive and active stretching exercises are a mandatory part of the student dorsal spine mobility program. Such exercises provide the required freedom level of the dancer's body. They prevent professional injuries to muscles and joints. These exercises must be included in the warm-up and the final stage of the choreography training.

The main means of the plastic language of any dance is a pose. The training aplomb in a pose is a complex and time-consuming process. This process requires the dancer to concentrate on the following analyzers: vestibular, motor, visual. We used test 11 to determine the level of aplomb in students.

The development of strength endurance is achieved by performing jumps on the spot with straight and/or bent legs; running on the spot at a fast pace; alternation - jumping with walking, jumping with a load, jumping rope. The pace should be close to the real concert and competition program. More approaches increase the number of repetitions. This leads to significant fatigue and the need to regulate breathing, stress, and rest.

In the case of reductions in-classroom training for future choreography teachers, more attention should be paid to the independent work of students. A component of such work is the increasing level of physical fitness: performing art tasks; independent compilation and demonstration of technical exercises; performance of art projects with group's students. The student must constantly improve their physical fitness and improve the appropriate functional abilities to perform complex dance movements (classical dance, folk-stage dance, modern dance).

The specifics of students' professional training (future teachers) determines the use of the following forms of the educational process organization: practical and individual training; a set of externship in the specialty. The forms of extracurricular work of students should be as follows: participation in concerts, competitions, festivals. This is an incentive and encouragement to develop physical qualities and self-improvement. We agree with other authors $[12,33]$ that such an active form of professional training provides consolidation and integration of formed theoretical knowledge; acquired practical skills and abilities in the methodology of teaching choreographic disciplines. 


\section{Conclusions}

It is recommended to constantly monitor future choreographers' physical fitness. This makes it possible to determine the effectiveness of the complex influence of professional disciplines on the students' physical fitness. Disciplines of professional training are the basis for acquiring the professional skills of dancers. This will help to improve the training program on time.
The exclusion of the discipline "Physical Education" from the training programs of choreography teachers requires appropriate compensation for specific physical activity. These can be students' independent classes in physical education. It also requires the correction of special training programs that include physical activity.

\section{Conflict of interest}

The authors declare no conflict of interest.

\section{References}

1. Gordiienko OI. Modern status and prospects of development of physical education of students of high schools. Scientist, 2018; 4(2): 37-40.

2. Kryventsova IV, Pashkevych SA, Khvorost MV. Current state of physical performance of pedagogical university students. Visnik NUChK, 2019;3(159):57-62. (In Ukrainian)

3. Platonova A, Podrigalo L, Iermakov S, Cieślicka M, Muszkieta R. Evaluation of physical development in ukrainian city pupils during 35 year-monitoring period (1974 - 2009). Coll Antropol, 2018;42(1):7-12.

4. Kuznecova O, Zubric'kij B, Sinicina O. Defining of the Level of Physical Preparedness of Students of the First Course of University. Fizichne vikhovannia, sport i kul tura $u$ suchasnomu suspil'stvi, 2015;3(31):147-152. (In Ukrainian).

5. Bilici M, Genç A. The effects of smoking addiction and physical activity on some respiratory functions in female university students. Pedagogy of Physical Culture and Sports. 2020;24(2):54-8. https://doi.org/10.15561/26649837.2020.0201

6. Shchur L. Evaluation of physical condition among university students in the field of art. Moloda sportivna nauka Ukraini, 2013;2:263-267. (In Ukrainian)

7. Marinchuk PI. The peculiarities of the physical state of students of music specilities. Health, sport, rehabilitation, 2018;1:67-72. (In Ukrainian).

8. Sanchez AC, Sanchez MO, Herrera-Peco I. Creative potential and personality of spanish students in higher education dance. Revista Electronica De Investigacion Docencia $Y$ Creatividad-Docrea, 2016;5:25-40.

9. Gao Lixiong. The Training Strategy of Image. Thinking in Choreographer, 3rd International Social Sciences and Education Conference (ISSEC 2018), 2018. P.583-586.

10.Petrovich V, Al'oshina A. Influence of Flexibility on Human's Organism and its Role in Sport. Fizichne vikhovannia, sport $i$ kul 'tura zdorov'ia u suchasnomu suspil'stvi, 2012;4(20):319322. (In Ukrainian)

11. Angioi M. Physical fitness and severity of injuries in contemporary dance. Journal Medical Problems of Performing Artists, 2009;3(1):26-29.

12.Blagova TO. Priorities of professional-practical training of the choreographer in conditions of institutions of higher education. Aktual'ni pitannia mistec'koi osviti ta vikhovannia, 2018;1(11):3-10. (In Ukrainian)

13.Kolnoguzenko BM, Makarova II. Modern dance and methods of its teaching, Kharkiv; 2015. (In Ukrainian)

14. Chuba V. Problems of professional qualities formation of future choreographers in the system of higher education. Problemi pidgotovki suchasnogo vchitelia, 2014;10:221227. (In Ukrainian)

15.Podrigalo LV, Yermakov SS, Rovnaya OA, Sotnikova-Meleshkina JV, Yermakova TS. Features of students' nutrition as a factor influencing health. Human Sport Med, 2019;19(4):103-110. https://doi.org/10.14529/hsm190412

16.Solonec' IuO. Features of Development of Flexibility and Methods of its Perfection for the Students of Faculty of Physical Education in the Process of Mastering of Choreographic Disciplines. Molodizhnij naukovij visnik, 2010;4:48-51. (In Ukrainian)

17.Zavgorodnia IeIe. Physical culture as a basis for the future choreographer formation. Naukovij visnik Donbasu, 2014;3: 34-40. (In Ukrainian)

18. Brown AC, Wells TJ, Schade ML, Smith DL, Fehling, PC. Effects of plyometric training versus traditional weight training on strength, power and aesthetic jumping ability in female collegiate dancers. Journal of Dance Medicine \& Science, 2007;11(2):38-44.

19.Khol'chenkova NM. Modern dance as a way of health care: basic characteristics and features of development. Visnik ChNPU, 2018;152(2):176-180. (In Ukrainian)

20.Yang Fan. A study on the cultural connotation of choreographer teaching in colleges and universities. Advances in Social Science Education and Humanities Research. 4th International Conference on Humanities and Social Science Research (ICHSSR), 2018;213. P.248-250.

21.Vietrins'ka AV. Innovations in modern choreographic professional education. Muzichne mistectvo $v$ osvitologichnomu diskursi, 2017;2:59-61. (In Ukrainian) https://doi.org/10.28925/2518-766X.20172.5961

22.Medvid' TA. Competent principles of future choreographers' professional training in classical university. Visnik NAKKKiM, 2018;2:234-238. (In Ukrainian)

23.Ivashchenko O, Khudolii O, Iermakov S, Lochbaum MR, Cieslicka M, Zukow W, et al. Intra-group factorial model as the basis of pedagogical control over motor and functional fitness dynamic of 14-16 years old girls. Journal of Physical Education and Sport, 2016;16(4):1190-1201. https://doi.org/10.7752/jpes.2016.04190

24.Ivashchenko O, Prykhodko V, Cieslicka M. Movement Coordination: Factor Structure of Development in 5th-7th Grade Girls. Teoriâ Ta Metodika Fìičnogo Vihovannâ, 2018; 18(1): 38-49. https://doi.org/10.17309/tmfv.2018.1.05

25.Menzel H-J, Chagas MH, Szmuchrowski LA, Araujo SR, Campos CE, Giannetti MR. Usefulness of the Jump-andReach Test in Assessment of Vertical Jump Performance. Percept Mot Skills, 2010;110:150-8. https://doi.org/10.2466/ pms.110.1.150-158

26.Rodríguez-Rosell D, Mora-Custodio R, Franco-Márquez F, Yáñez-García JM, González-Badillo JJ. Traditional vs. Sport-Specific Vertical Jump Tests: Reliability, Validity, and Relationship With the Legs Strength and Sprint Performance in Adult and Teen Soccer and Basketball Players. Journal of Strength and Conditioning Research, 2017;31:196-206. https://doi.org/10.1519/JSC.0000000000001476

27.The President's Challenge. Physical Activity \& Fitness Awards Program. 2009-2010. [Internet]. 2009. [updated 
2019 Jun 15; cited 2020 Jun 30]. Available from: http://www. newton.k12.in.us/hs/pe/images/physical-fitness-guide.pdf

28.Testing Physical Fitness. Eurofit. Experimental Battery. Provisional handbook. Strasbourg; 1983.

29.Liengme B, Hekman K. Basic Operations. Liengme's Guide to Excel ${ }^{\circledR} 2016$ for Scientists and Engineers. Elsevier; 2020, p. 15-46. https://doi.org/10.1016/B978-0-12-818249-9.00002-9

30.Wang Yang, Liu Qingtang. Effects of Game-Based Teaching on Primary Students' Dance Learning: The Application of the Personal Active Choreographer. International Journal of Game-Based Learning, 2020;10(1):19-36. https://doi.org/10.4018/IJGBL.2020010102

31.Kizim V, Andrieieva R. Technology of teaching rhythmics and choreography and influence on physical preparedness of students of the institute of physical education and sport. Fizichna kul'tura, sport ta zdorov'ia nacii, 2016;20:71-75. (In Ukrainian)

32.Kozina Z, Uvarova N, Cieslicka M, Bejtka M, Jagiełło M. Experimental substantiation of the program of the annual cycle of preparation of climbers 16-17 years to the competitive discipline «Climbing Combined». Journal of Physical Education and Sport, 2020;20(Suppl. Issue 2);1250 - 1256. https://doi.org/10.7752/jpes.2020.s2174

33. Rostovs'ka IuO. To the problem of introduction of innovative technologies in professional training of future teachers of choreography. Problemi mistec'koi osviti, 2018;3:60-165. (In Ukrainian)

\section{Information about the authors:}

Olga V. Limanskaya; http://orcid.org/0000-0002-4968-7515; olgalymanska@gmail.com; H.S. Skovoroda Kharkiv National Pedagogical University; Kharkiv, Ukraine.

Irina V. Kriventsova; (Corresponding author); http://orcid.org/0000-0001-6931-3978; kriventsova.ira@ukr.net; H.S. Skovoroda Kharkiv National Pedagogical University; Kharkiv, Ukraine.

Leonid V. Podrigalo; http://orcid.org/0000-0002-7893-524X; I.podrigalo@mail.ru; Department of Medical Science, Kharkiv State Academy of Physical Culture; Klochkovskaya str. 99, Kharkov, 61022, Ukraine.

Olena V. Yefimova; https://orcid.org/0000-0001-5532-7324; halaburdina_e@ukr.net; H.S. Skovoroda Kharkiv National Pedagogical University; Kharkiv, Ukraine.

Marina Jagiello; http://orcid.org/0000-0001-5591-4537; wjagiello1@wp.pl; Department of Theory of Sport and Human Motority, Gdansk University of Physical Education and Sport; Kazimierza Górskiego 1, 80-336 Gdańsk, Poland.

Cite this article as:

Limanskaya O, Kriventsova I, Podrigalo L, Yefimova O, Jagiello M. The influence of professional training disciplines on the physical fitness level of the folk dance department students. Pedagogy of physical culture and sports, 2020;24(5):248-254 https://doi.org/10.15561/26649837.2020.0505

This is an Open Access article distributed under the terms of the Creative Commons Attribution License, which permits unrestricted use, distribution, and reproduction in any medium, provided the original work is properly cited (http://creativecommons.org/licenses/by/4.0/deed.en).

Received: 16.04 .2020

Accepted: 16.05.2020; Published: 30.10 .2020 